\title{
Relevance of application of the Yamaguchi criteria for patients with suspected juvenile idiopathic arthritis in the absence of arthritis symptoms
}

\author{
Znaczenie stosowania kryteriów Yamaguchi u osób z podejrzeniem młodzieńczego \\ idiopatycznego zapalenia stawów w przypadku braku objawów zapalenia stawów
}

\author{
Azza El Hamshary ${ }^{1}$, Huda Marzouk ${ }^{1}$, Nawal M. Khalifa², Dina H. El Sawy² \\ ${ }^{1}$ Department of Pediatrics, Faculty of Medicine, Cairo University, Cairo, Egypt \\ ${ }^{2}$ Department of Pediatrics, Research Institute of Ophthalmology, Cairo, Egypt
}

Key words: systemic-onset juvenile idiopathic arthritis, adult-onset Still's-disease, ILAR criteria, Yamaguchi criteria.

Słowa kluczowe: młodzieńcze idiopatyczne zapalenie stawów o początku układowym, choroba Stilla u dorosłych, kryteria ILAR, kryteria Yamaguchi.

\begin{abstract}
Sum mary
Aim of the study: Systemic juvenile idiopathic arthritis (s)IA) is characterized by systemic inflammation beside arthritis. Many children may have delayed onset of arthritis. We aimed in our study to determine whether the Yamaguchi criteria (for adult onset Still's disease) can be applied in diagnosis of sJIA, especially in absence of arthritis. Material and methods: The cross-sectional study included $30 \mathrm{pa}$ tients diagnosed with $\mathrm{s}$ IA, those patients diagnosed by the treating paediatrician with 'definite' sJIA (fulfilling the International League of Associations for Rheumatology [ILAR] classification criteria) or 'suspected' sJIA (not fulfilling the ILAR criteria). The fulfilment of the variables in both the ILAR criteria and the Yamaguchi criteria was recorded for each patient at the time of first presentation.

Results: We included 16 boys and 14 girls. Ten patients were diagnosed with suspected SIIA due to the presence of typical systemic features but failed to fulfil the ILAR criteria, especially absence of arthritis in 9 of them. Yamaguchi criteria were fulfilled in a higher number of patients $(23 / 30,76.7 \%)$ as compared to those who fulfilled the ILAR criteria (20/30, 66.7\%). All 10 patients with suspected s)IA fulfilled the Yamaguchi criteria, and 11 patients (36.7\%) had delayed onset of arthritis. Overall, the 30 patients (100\%) in the present study fulfilled either ILAR criteria or Yamaguchi criteria.

Conclusions: There is a subgroup of patients with SJIA in whom arthritis is absent or delayed. The use of the Yamaguchi criteria in this subgroup of patients may be useful for early diagnosis and treatment of SIIA. Thus, further studies are needed to integrate supplementary criteria that increase the strength of both the Yamaguchi and the ILAR criteria.
\end{abstract}

\section{Streszczenie}

Cel pracy: Młodzieńcze idiopatyczne zapalenie stawów (MIZS) o początku układowym charakteryzuje to, że zapaleniu stawów towarzyszy ogólnoustrojowy stan zapalny. Początek zapalenia stawów u dzieci często występuje z opóźnieniem. Celem badania było ustalenie, czy możliwe jest stosowanie kryteriów Yamaguchi (używanych w chorobie Stilla $u$ dorosłych) do rozpoznawania MIZS o początku układowym, zwłaszcza przy braku objawów zapalenia stawów. Materiat i metody: Badanie przekrojowe obejmowało 30 pacjentów z MIZS o początku układowym, których pediatra zakwalifikował jako „zdecydowany” przypadek MIZS (spełnione kryteria klasyfikacji ILAR) lub „podejrzenie” MIZS (niespełnione kryteria klasyfikacji ILAR). Dla każdego pacjenta odnotowano wszystkie kryteria ILAR i kryteria Yamaguchi spełnione w chwili pierwszego zgłoszenia.

Wyniki: Do badania zakwalifikowano 16 chłopców i 14 dziewczynek. U 10 pacjentów podejrzewano MIZS o początku układowym z uwagi na obecność typowych cech układowych przy jednoczesnym braku spełnienia kryteriów ILAR, a zwłaszcza braku objawów zapalenia stawów u 9 z tych chorych. W badaniu więcej pacjentów spełniało kryteria Yamaguchi (23/30; 76,7\%) niż kryteria ILAR (20/30; 66,7\%). Kryteria Yamaguchi spełniało 10 pacjentów z podejrzeniem MIZS o początku układowym, a u 11 osób (36,7\%) zapalenie stawów wystąpiło z opóźnieniem. Ogółem 30 pacjentów uczestniczących w badaniu (100\%) spełniało albo kryteria ILAR, albo kryteria Yamaguchi.

Wnioski: Istnieje podgrupa pacjentów z MIZS o początku układowym, u których objawy zapalenia stawów nie są obecne bądź występują z opóźnieniem. Wykorzystanie kryteriów Yamaguchi w tej

Address for correspondence

Azza El Hamshary, Department of Pediatrics, Faculty of Medicine, Cairo University, Cairo, Egypt, e-mail: ahamshary@hotmail.com Submitted: 31.10 .2014 


\section{Introduction}

Juvenile idiopathic arthritis (JIA) is the most common chronic rheumatic disease of childhood and describes a group of clinically heterogeneous arthritides which begin before the age of 16 years and persist for at least 6 weeks [1]. At onset, systemic JIA, which represent nearly $10 \%$ of all cases of JIA, is distinguished from other forms by prominence of extra-articular features such as spiking fever, typical fleeting pink macular rash, generalized lymphadenopathy, hepatosplenomegaly, and occasionally polyserositis [2]. The pathogenic mechanisms underlying the heterogeneity of systemic $\|$ A are not well understood [3]. The aetiology of JIA is still unknown, and the genetic component is complex [4].

In comparison between SJIA and other JIA groups, one important difference is that arthritis may be a non-prominent and/or a delayed-onset manifestation. Arthritis has been reported to be a manifestation delayed up to 10 years in a subset of sJIA patients [5].

International League of Associations for Rheumatology (ILAR) criteria require the presence of arthritis to define a patient as having SJIA [6]. Strict adherence to the ILAR criteria may lead to delay in the diagnosis of sJIA, resulting in early morbidity and mortality in SIA patients [5].

Recently researchers have reported that sJIA patients before the onset of arthritis (suspected sJIA) appear clinically and immunologically similar to patients fulfilling the ILAR criteria (definite SJIA) [7].

Most studies comparing Still's disease (SJIA) in children and adult onset Still's disease (AOSD) have not grupie pacjentów może być przydatne w rozpoznawaniu i leczeniu choroby. Niezbędne są dalsze badania nad stosowaniem kryteriów dodatkowych zwiększających znaczenie zarówno kryteriów Yamaguchi, jak i kryteriów ILAR.

found a significant difference in the clinical manifestation at the time of presentation [8-12].

Various criteria are available for the diagnosis of AOSD, and none of these criteria depend heavily on the presence of arthritis. The Yamaguchi criteria are the most sensitive (96\%) and specific (92\%) for the diagnosis of AOSD $[13,14]$.

The aim of the present study was to determine the possible application of the Yamaguchi criteria in the diagnosis of children presenting with typical systemic manifestation of sJIA including serositis but still not having developed arthritis (named as 'suspected' sJIA), for early diagnosis and treatment of sJIA patients.

\section{Material and methods}

The study was conducted between March 2011 and March 2013 in the Rheumatology Clinic of the Cairo University Specialized Pediatric Hospital. The study was conducted retrospectively using hospital records and was approved by the Cairo University Clinical Research Ethics Committe. It included 30 patients, only patients diagnosed by the treating paediatrician as having 'definite' SIIA (fulfilling the ILAR classification criteria) or 'suspected' SIIA (not fulfilling the ILAR criteria) were included. All patients were diagnosed with SIIA (definite or suspected) in the last 3 years (Table I).The study group compromised 16 males (53.3\%) and 14 females (46.7\%). Mean age of patients was $9.03 \pm 4.02$ years; mean age at diagnosis was $6.52 \pm 3.20$ years and mean duration of symptoms at time of presentation was $106.33 \pm 76.36$ days. Mean duration of

Table I. Variables of the ILAR and Yamaguchi criteria

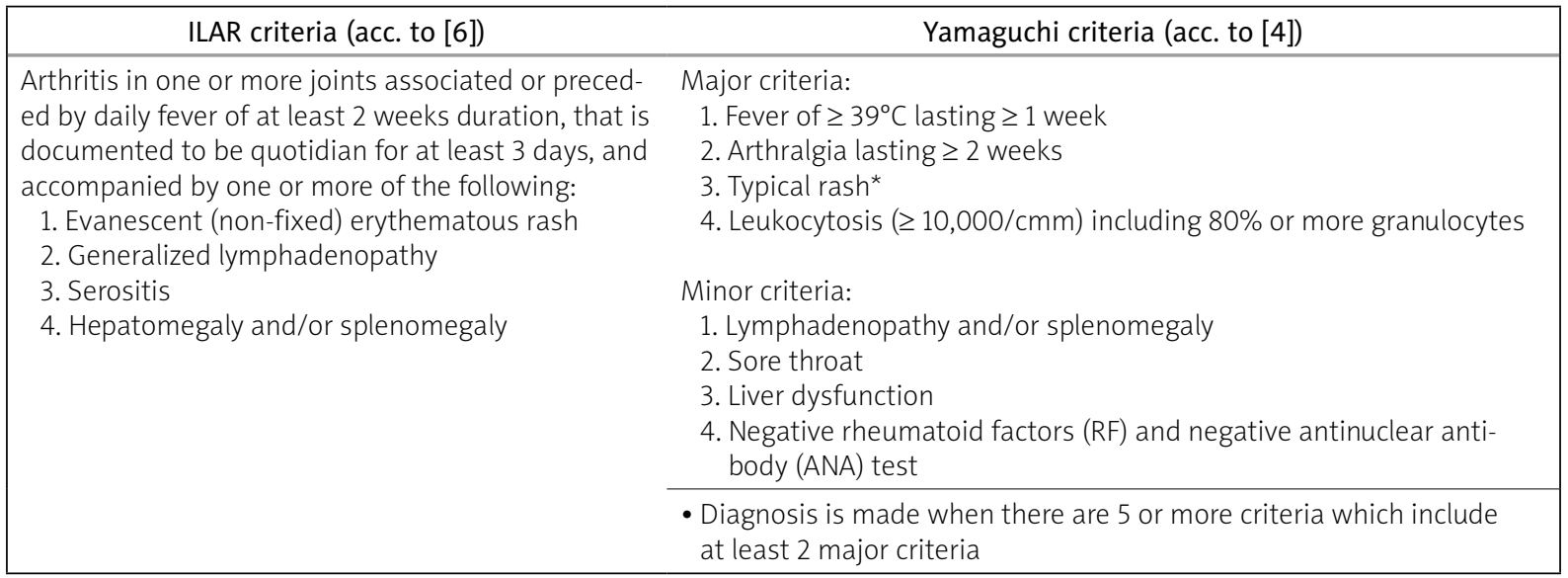

*Typical rash = non-pruritic macular or maculopapular salmon coloured rash (usually over the trunk or extremities while febrile) 
Table II. Clinical and laboratory data of patients in the study $(n=30)$



the delay between onset of systemic manifestation and onset of arthritis was $29.10 \pm 72.18$ days. Clinical and laboratory data of patients are summarized in Table II.

All included patients had been investigated to rule out malignancies and infections as causes of fever of unknown origin (FUO).

The fulfilment of the variables in both the ILAR criteria and the Yamaguchi criteria was recorded for each patient at the time of first presentation to our hospital (refer to Table I for the criteria) $[8,15]$.

We considered the following symptoms present whether patients had it at presentation at our hospital or at any time during the course of the disease in the past history: characteristic fever, arthralgia, serositis, and sore throat. However, clinical signs (typical rash, splenomegaly, hepatomegaly and lymphadenopathy) and laboratory criteria (leucocytosis, liver dysfunction and negative ANA, RF) were considered present if they had been observed and reported at the time of presentation at our hospital.

Patients were considered to have arthritis only if the arthralgia was associated with either significant swelling or any 2 of the following findings: increased warmth over the joint, pain with limitation of range of motion, deformity, which had been documented by the physician at the time of presentation. The duration between onset of fever and onset of arthritis was recorded from the patients' files and by asking the parent.

The study protocol was approved by the Institutional Ethical Committee and written consent was obtained from the parents of all participating subjects before the study.

\section{Statistical methods}

Data analysis was performed through Statistical Package for Social Sciences (SPSS) version 15. Data are expressed as mean, median, standard deviation (SD) and percentage. Comparison was performed through the $\chi^{2}$ test for qualitative variables. Comparison between 2 quantitative variables was performed through the $t$-test, while one-way ANOVA was used for comparison between more than 2 quantitative variables. Pearson's correlation was also used. P-values less than 0.05 were considered significant.

\section{Results}

All the 30 patients had fever (ILAR and Yamaguchi criteria). The second most commonly fulfilled component was rash (90\%) (ILAR and Yamaguchi criteria), then arthralgia $\geq 2$ weeks (Yamaguchi criteria) was seen in 25 patients (83.3\%) and only 21 patients (70\%) had arthritis (ILAR criteria) at presentation.

In our study, 23 patients (76.7\%) fulfilled Yamaguchi criteria and 20 patients (66.7\%) fulfilled ILAR criteria. Ten patients who failed to fulfil the ILAR criteria fulfilled the Yamaguchi criteria, and among 20 patients who fulfilled the ILAR criteria 7 patients did not fulfil the Yamaguchi criteria (Table III).

Comparison between patients who fulfilled the ILAR criteria (definite $S J \mid A$ ) and those who did not fulfil the ILAR criteria (suspected sJIA) is shown in Table IV.

The mean age at the time of the study and at diagnosis of children with definite sJIA was significantly higher than in those with 'suspected' sJIA ( $p=0.02,0.04$, respectively). The mean erythrocyte sedimentation rate (ESR) was significantly higher in patients with 'suspected' $s$ JIA than those with definite sJIA ( $p=0.04)$.

In 10 patients who failed to fulfil the ILAR criteria, 9 of them had no arthritis. So our 30 patients were grouped according to the presence or absence of arthritis. The comparison between the 2 groups is shown in Table $\mathrm{V}$.

Mean age of patients was significantly higher and mean duration of fever was significantly prolonged in patients with arthritis ( $p=0.04$ and 0.01 , respectively). Rash was significantly more frequent in patients with arthritis $(p=0.02)$ and lymphadenopathy was significantly more frequent in patients without arthritis ( $p=$ 
Table III. Patients who fulfilled the ILAR criteria and Yamaguchi criteria

\begin{tabular}{|lccc|}
\hline & ILAR criteria fulfilled & ILAR criteria not fulfilled & Total \\
\hline Yamaguchi criteria fulfilled & $n=13$ & $n=10$ & $n=23$ \\
\hline Yamaguchi criteria not fulfilled & $n=7$ & $n=0$ & $n=7$ \\
\hline Total & $n=20$ & $n=10$ & $n=30$ \\
\hline
\end{tabular}

Table IV. Comparison between patients with definite sJIA and those with suspected sJIA

\begin{tabular}{|c|c|c|c|}
\hline Characteristics & $\begin{array}{c}\text { Definite sJIA } \\
(n=20)\end{array}$ & $\begin{array}{l}\text { Suspected sJIA } \\
\quad(n=10)\end{array}$ & $p$-value \\
\hline Age $($ mean $\pm S D)$ & $10.25 \pm 3.88$ & $6.60 \pm 3.24$ & 0.02 \\
\hline Male/female ratio & 0.5 & 1.5 & 0.5 \\
\hline Mean age at diagnosis of disease (years) & $7.30 \pm 3.25$ & $4.95 \pm 2.59$ & 0.04 \\
\hline Mean duration of symptoms at time of presentation (days) & $99 \pm 56$ & $121 \pm 108.67$ & 0.5 \\
\hline Average number of affected joints & $3.45 \pm 1.47$ & $4 \pm 1.25$ & 0.3 \\
\hline Number of patients with arthralgia & $16(80 \%)$ & $9(90 \%)$ & 0.4 \\
\hline Number of patients with rash & $20(100 \%)$ & $7(70 \%)$ & 0.03 \\
\hline Number of patients with sore throat & $10(50 \%)$ & $6(60 \%)$ & 0.5 \\
\hline Number of patients with generalised lymphadenopathy & $2(10 \%)$ & $1(10 \%)$ & 0.7 \\
\hline Number of patients with lymphadenopathy & $3(15 \%)$ & $5(50 \%)$ & 0.06 \\
\hline Number of patients with hepatomegaly & $4(20 \%)$ & $2(20 \%)$ & 0.7 \\
\hline Number of patients with splenomegaly & $3(15 \%)$ & $2(20 \%)$ & 0.6 \\
\hline Number of patients with serositis & $5(25 \%)$ & $1(10 \%)$ & 0.3 \\
\hline Mean ESR $(\mathrm{mm} / \mathrm{h})$ & $91.8 \pm 30$ & $110.9 \pm 19.34$ & 0.04 \\
\hline Mean haemoglobin (gm/dl) & $9.83 \pm 1.85$ & $8.8 \pm 1.84$ & 0.2 \\
\hline Mean WBC $\left(\times 10^{3} / \mathrm{mm}^{3}\right)$ & $12.94 \pm 5.66$ & $16.9 \pm 4.15$ & 0.06 \\
\hline Mean platelet count $\left(\times 10^{3} / \mathrm{mm}^{3}\right)$ & $521.15 \pm 182.02$ & $542.6 \pm 186.61$ & 0.8 \\
\hline Mean ALT $(\mathrm{U} / \mathrm{I})$ & $42.7 \pm 54.09$ & $28.5 \pm 15.01$ & 0.4 \\
\hline Mean AST (U/I) & $46.8 \pm 93.44$ & $29 \pm 11.6$ & 0.5 \\
\hline
\end{tabular}

$=0.03)$. Mean ESR and mean WBC were significantly higher in patients without arthritis ( $p=0.04$ and 0.05 , respectively). During follow-up (until the end of our study) 2 patients with 'suspected' JIA developed arthritis. In those 2 patients, the delay between first presentation and development of arthritis was 6 months in 1 child and 4 months in the other.

All the 20 patients who fulfilled the ILAR criteria had arthritis at presentation. However, with proper history taking from parents of patients, 11 of these patients had a history of delay between onset of systemic features and onset of their arthritis. The mean duration of the delay was $43.65 \pm 85.35$ days and the median was 16.5 days.

\section{Discussion}

The strict diagnosis of SJIA (previously labelled as Still's disease) by fulfilment of all ILAR criteria leads to the presence of children who clearly have this disease, but cannot be classified as having SJIA due to the absence of arthritis [4]. Extensive research on the pathogenesis of SJIA has been done since the publication of the ILAR criteria in 2004.

Certain cytokines and biomarkers which are characteristically increased in SJIA have been discovered by many researchers, for example, interleukin-18 (IL-18) $[15,16]$, macrophage migration inhibitory factor (MIF) $[17,18]$, myeloid related proteins 8 and 14 (MRP 8/14) $[19,20]$, soluble IL-receptor [21], S100A12 [22] and others. The utility of these biomarkers in diagnosis of patients with SJIA has been studied [15, 18, 20, 22, 23], and it was revealed that these biomarkers are helpful not only for diagnosing SJIA but also for distinguishing children with SJIA from patients with other subtypes of JIA, other inflammatory diseases and infection [4]. Also, Vastert et al. [7] showed that the clinical characteristics, 
Table V. Comparison between patients with arthritis and those without arthritis

\begin{tabular}{|c|c|c|c|}
\hline Characteristics & Patients with arthritis $(n=21)$ & Patients without arthritis $(n=9)$ & $p$-value \\
\hline Age $($ mean $\pm S D)$ & $9.95 \pm 4.02$ & $6.89 \pm 3.30$ & 0.04 \\
\hline Male/female ratio & 1.1 & 1.25 & 0.6 \\
\hline $\begin{array}{l}\text { Mean age at diagnosis of disease } \\
\text { (years) }\end{array}$ & $7.10 \pm 3.30$ & $5.17 \pm 2.65$ & 0.1 \\
\hline $\begin{array}{l}\text { Mean duration of symptoms at time } \\
\text { of presentation (days) }\end{array}$ & $104.29 \pm 59.71$ & $111.11 \pm 110.39$ & 0.8 \\
\hline $\begin{array}{l}\text { Mean duration of fever at time } \\
\text { of presentation (days) }\end{array}$ & $88.57 \pm 53.22$ & $42.33 \pm 22.67$ & 0.01 \\
\hline Number of patients with arthralgia & $16(76.2 \%)$ & $9(100 \%)$ & 0.1 \\
\hline Number of patients with rash & $21(100 \%)$ & $6(66.7 \%)$ & 0.02 \\
\hline Number of patients with sore throat & $11(52.4 \%)$ & $5(55.6 \%)$ & 0.6 \\
\hline $\begin{array}{l}\text { Number of patients with generalised } \\
\text { lymphadenopathy }\end{array}$ & $2(9.5 \%)$ & $1(11.1 \%)$ & 0.7 \\
\hline $\begin{array}{l}\text { Number of patients with lymphade- } \\
\text { nopathy }\end{array}$ & $3(14.3 \%)$ & $5(55.6 \%)$ & 0.03 \\
\hline Number of patients with hepatomegaly & $4(19 \%)$ & $2(22.2 \%)$ & 0.6 \\
\hline Number of patients with splenomegaly & $3(14.3 \%)$ & $2(22.2 \%)$ & 0.5 \\
\hline Number of patients with serositis & $5(23.8 \%)$ & $1(11.1 \%)$ & 0.4 \\
\hline Mean ESR $(\mathrm{mm} / \mathrm{h})$ & $92.19 \pm 29.30$ & $112.11 \pm 20.11$ & 0.04 \\
\hline Mean haemoglobin (gm/dl) & $9.61 \pm 2.07$ & $9.18 \pm 1.45$ & 0.6 \\
\hline Mean WBC $\left(\times 10^{3} / \mathrm{mm}^{3}\right)$ & $13.09 \pm 5.55$ & $17 \pm 4.39$ & 0.05 \\
\hline Mean platelet count $\left(\times 10^{3} / \mathrm{mm}^{3}\right)$ & $526.81 \pm 179.3$ & $531.78 \pm 194.57$ & 0.9 \\
\hline Mean ALT (U/l) & $41.43 \pm 53.04$ & $29.89 \pm 15.22$ & 0.5 \\
\hline Mean AST (U/I) & $45.52 \pm 91.26$ & $30 \pm 11.83$ & 0.6 \\
\hline
\end{tabular}

the mean value of many of the above biomarkers and the response to the therapy in 'suspected' SJIA patients without arthritis were similar to those in SJIA patients fulfilling the ILAR criteria. Nevertheless, these biomarkers are not routinely available and are expensive.

On the other hand, many studies have involved the comparison between children with sJIA and adults with AOSD, and most of these studies revealed a lack of any significant difference between both groups as regard systemic features [8-12], the articular manifestation or sequelae [8, 10-12]. However, Pay et al. [24] reported a few significant differences between paediatric and adult patients as regards clinical and laboratory features. Likewise, Lin et al. [9] reported differences between sJIA children and AOSD adults in articular outcomes.

In spite of these few differences, the presence of a large number of similarities allows the authors to consider that AOSD and SJIA may be the same disease and children may react differently [8-12, 24]. So considering these similarities, sJIA patients were expected to fulfil the diagnostic criteria of AOSD, and we applied this expectation in our study and used the Yamaguchi criteria (a relatively simple tool with clinical and basic laboratory features). We found that $76.7 \%$ of our patients fulfilled the Yamaguchi criteria and only $66.7 \%$ fulfilled the ILAR criteria for SJIA, as in the studies by Kumar et al. [4] and Behrens et al. [25], who reported that ILAR criteria were fulfilled in $58 \%$ and $31 \%$ of the SIIA patients respectively. In our study, the failure of ILAR criteria was mainly due to the absence of arthritis. Also we found that 13 (65\%) patients with definite SIIA $(n=20)$ fulfilled the Yamaguchi criteria - not as surprising as the report by Luthi et al. [10], who found that all 9 of their sJIA patients fulfilled the Yamaguchi criteria.

Pay et al. [24] found that all SJIA patients in their study fulfilled the ILAR criteria, 5/25 (20\%) sJIA patients did not have arthritis at initial presentation, and we found in our study that 11/20 (55\%) sJIA patients did not have arthritis at initial presentation.

The definition of SIIA by the Childhood Arthritis and Rheumatology Research Alliance (CARRA) for initiating treatment in patients was different from the ILAR criteria for SIIA in the absence of arthritis and was based on fever and systemic features such as characteristic rash, 
adenopathy and serositis. Provided that malignancy and infection have been excluded, the opinion of CARRA was that the ILAR criteria might lead to exclusion of patients who need to be treated as having SIIA [26].

In our study, the Yamaguchi criteria seem to be more helpful in patients with the absence of arthritis (9/9; $100 \%)$ as compared to patients with arthritis (14/20; $70 \%)$. These results are similar to the finding by Kumar et al. [4], who reported the Yamaguchi criteria in the absence of arthritis in 12/13 patients (92.3\%) as compared to patients with arthritis (11/18; $61.1 \%)$.

Characteristic evanescent rash is considered as one of the features in SIIA $[5,26]$. We observed the rash in 27 patients (90\%), similar to the value in Europe and North America reported by Behrens et al. [25] and Modesto et al. [27], who found the presence of rash in about $80 \%$ of patients. However, Kumar et al. [4], Seth et al. [28] and Singh et al. [29] reported the prevalence of rash as between $27 \%$ and $58 \%$ in Indian sJIA patients. The lower incidence of rash in the studies in India may be explained by darker skin colour that makes the rash difficult to see. This difficulty may be considered as a further limitation of the ILAR criteria in patients with darker skin colours.

In our study, when both (ILAR and Yamaguchi) criteria were used either alone or in combination, all our patients ( $n=30$ ) could be diagnosed with sJIA, similarly to the observations reported by Kumar et al. [4].

\section{Limitation}

Possibly in our study it would be useful to take longterm follow-up data, as it is possible that suspected sJIA may evolve into another rheumatological disorder disease. Additionally, sore throat as part of the Yamaguchi criteria can be reduced specifically in children.

\section{Conclusions}

Arthritis as an essential criterion for the diagnosis of SIIA may be absent or delayed in the subgroup of SIIA. Some changes in the ILAR criteria for sJIA to make them more inclusive are suggested. Application of the Yamaguchi criteria (arthritis as an essential criteria is not considered) might allow the criteria to be more clinically useful. These changes may allow early diagnosis and treatment of children with SJIA and prevent some of the morbidity associated with delayed diagnosis of sJIA.

The authors declare no conflict of interest.

\section{References}

1. Ravelli A, Martini A. Juvenile idiopathic arthritis. Lancet 2007; 369: 767-778.
2. Schneider R, Laxer RM. Systemic onset juvenile rheumatoid arthritis. Baillieres Clin Rheumatol 1998; 12: 245-271.

3. Ramanan AV, Grom AA. Does systemic-onset juvenile idiopathic arthritis belong under juvenile idiopathic arthritis? Rheumatology (Oxford) 2005; 44: 1350-1353.

4. Kumar S, Kunhiraman DS, Rajam L. Application of Yamaguchi criteria for classification of "suspected" systemic juvenile idiopathic arthritis (sJIA). Pediatr Rheumatol Online J 2012; 10: 40-48.

5. De Benedetti F, Schneider R. Systemic juvenile idiopathic arthritis. In: Textbook of Pediatric Rheumatology. 6th ed. Cassidy JT, Petty RE, Laxer RM, Lindsley CB (eds.). Elsevier, Philadelphia 2011: 236-248.

6. Petty RE, Southwood TR, Manners P, et al. International League of Association for Rheumatology classification of juvenile idiopathic arthritis: second revision, Edmonton, 2001. J Rheumatol 2004; 31: 390-392.

7. Vastert S, De Jager W, Noordman BJ, et al. Anakinra in the early phase of systemic onset JIA: before the onset of arthritis. Ann Rheum Dis 2011; 70 (Suppl 3): 408.

8. Cabane J, Michon A, Ziza JM, et al. Comparison of long term evolution of adult onset and juvenile onset Still's disease, both followed up for more than 10 years. Ann Rheum Dis 1990; 49: 283-285.

9. Lin SJ, Chao HC, Yan DC. Different articular outcomes of Still's disease in Chinese children and adults. Clin Rheumatol 2000; 19: 127-130.

10. Luthi F, Zufferey P, Hofer MF, So AK. Adolescent-onset Still's disease: characteristics and outcome in comparison with adult-onset Still's disease. Clin Rheumatol 2002; 20: 427-430.

11. Uppal SS, Pande IR, Kumar A, et al. Adult onset Still's disease in northern India: comparison with juvenile onset Still's disease. Br J Rheumatol 1995; 19: 424-430.

12. Tanaka S, Matsumoto Y, Ohnishi H, et al. Comparison of clinical features of childhood and adult onset Still's disease. Ryumachi 1991; 31: 511-518.

13. Yamaguchi M, Ohta A, Tsunematsu T, et al. Preliminary criteria for classification of adult Still's disease. J Rheumatol 1992; 19: 424-430.

14. Masson C, Le Loet X, Liote F, et al. Comparative study of 6 types of criteria in adult Still's disease. J Rheumatol 1996; 23: 495-497.

15. Maeno N, Takei S, Nomura Y, et al. Highly elevated serum levels of interleukin 18 in systemic juvenile idiopathic arthritis but not in other juvenile idiopathic arthritis subtypes or in Kawasaki disease: comment on the article by Kawashima et al. Arthritis Rheum 2002; 46: 2539-2541. Author replay 2541-2542.

16. de Jager W, Vastert SJ, Beekman JM, et al. Defective phosphorylation of interleukin-18 receptor B causes impaired natural killer cell function in systemic-onset juvenile idiopathic arthritis. Arhtritis Rheum 2009; 60: 2782-2793.

17. Donn RP, Shelley E, Ollier WE, Thomson W. For the British Paediatric Rheumatology Study Group: A novel 5'-flanking region polymorphism of macrophage migration inhibitory factor is associated with systemic-onset juvenile idiopathic arthritis. Arthritis Rheum 2001; 44: 1782-1785.

18. Meazza C, Travaglino P, Pignatti P, et al. Macrophage migration inhibitory factor in patients with juvenile idiopathic arthritis. Arthritis Rheum 2002; 46: 232-237. 
19. Frosch M, Ahlmann M, Vogl T, et al. The myloid-related proteins 8 and 14 complex, a novel ligand of toll-like receptor 4 , and interleukin-1 beta form a positive feedback mechanism in systemic-onset juvenile idiopathic arthritis. Arthritis Rheum 2009; 60: 883-891.

20. Holzinger D, Frosch M, Kastrup A, et al. The Toll-like receptor 4 agonist MRP8/14 protein complex is a sensitive indicator for disease activity and predicts relapses in systemic onset juvenile idiopathic arthritis. Ann Rheum Dis 2012; 71: 974-980.

21. Bleesing J, Prada A, Siegel DM, et al. The diagnostic significance of soluble CD163 and soluble interleukin-2 receptor alpha-chain in macrophage activation syndrome and untreated new-onset systemic juvenile idiopathic arthritis. Arthritis Rheum 2007; 56: 965-971.

22. Wittkowski H, Frosch M, Wulffraat N, et al. S100A12 is a novel molecular marker differentiating systemic - onset juvenile idiopathic arthritis from other causes of fever of unknown origin. Arthritis Rheum 2008; 58: 3924-3931.

23. de Jager W, Hoppenreijs EP, Wulffraat NM, et al. Blood and synovial fluid cytokine signatures in patients with juvenile idiopathic arthritis: a cross sectional study. Ann Rheum Dis 2007; 66: 589-598.

24. Pay S, Türkçapar N, Kalyoncu M, et al. A multicentre study of patients with adult-onset Still's disease compared with systemic juvenile idiopathic arthritis. Clin Rheumatol 2006; 25 . 639-644.

25. Behrens EM, Beukelman T, Gallo L, et al. Evaluation of the presentation of systemic onset juvenile rheumatoid arthritis: data from the Pennsylvania Systemic Onset Juvenile Arthritis Registry (PASOJAR). J Rheumatol 2008; 35: 343-348.

26. DeWitt EM, Kimura Y, Beukelman T, et al. Consensus treatment plans for new-onset systemic juvenile idiopathic arthritis. Arthritis Care Res (Hoboken) 2012; 64: 1001-1010.

27. Modesto C, Woo P, García-Consuegra J, et al. Systemic onset juvenile chronic arthritis, polyarticular pattern and hip involvement as markers for a bad prognosis. Clin Exp Rheumatol 2001; 19: 211-217.

28. Seth V, Kabra SK, Semwal OP, Jain Y. Clinicoimmunological profile in juvenile rheumatoid arthritis - an indian experience. Indian J Pediatr 1996; 63: 293-300.

29. Singh S, Salaria M, Kumar L, et al. Clinicoimmunological profile of juvenile rheumatoid arthritis at Chandigarh. Indian Pediatr 1999; 36: 449-454. 